\title{
NONLINEAR VIBRATION ANALYSIS OF PREBUCKLING AND POSTBUCKLING IN LAMINATED COMPOSITE BEAMS
}

\author{
G. ABDOLLAHZADEH ${ }^{1}$, M. AHMADI ${ }^{2}$
}

\begin{abstract}
In this stud y, we attempt to analyse free nonlinear vibrations of buckling in laminated composite beams. Two new methods are applied to obtain the analytical solution of the nonlinear governing equation of the problem. The effects of different parameters on the ratio of nonlinear to linear natural frequencies of the beams are studied. These methods give us an agreement with numerical results for the whole range of the oscillation amplitude.
\end{abstract}

Keywords: Nonlinear vibration, composite beams, analytical methods

\section{INTRODUCTION}

Nonlinear vibrations of beams have occurred in many engineering applications. Most of the studies on the nonlinear vibration analysis which have been done on isotropic beams (Qaisi, 1993; Guo and Zhong, 2004; Xie et al., 2002; Nayfeh and Nayfeh, 1995; Bhashyam and Prathap, 1980; Carlos et al., 2004). Azrar et al., (1999) developed a semi analytical approach based on Lagrange's principle and the harmonic balance method for the nonlinear dynamic response of beams. The large amplitude free vibrations of uniform beams using a relatively simple and accurate finite element formulation has been studied by Gupta et al., (2009).

\footnotetext{
${ }^{1}$ Assoc. Prof., Faculty of Civil Engineering, Babol University of Technology, Babol, Iran, e-mail: abdollahzadeh@nit.ac.ir

${ }^{2}$ Department of Civil Engineering, Aryan Institute of Science and Technology, Babol, Iran, e-mail: ahmadi.morteza68@gmail.com
} 
On the other hand, a few studies which have reported on the nonlinear free vibrations of composite beams (Kapania and Raciti, 1989; Singh et al., 1991; Ganapathi et al., 1998; Malekza deh and Vosoughi, 2009). Kisa (2004) presented a new method for the numerical modeling of the free vibration of a cantilever composite beam having multiple open and non-propagating cracks. The higher order theory for composite sandwich beam with viscoelastic core to improve the "Mead \& Markus" theory has been studied by Arvin et al., (2010). They showed that by increasing the fiber angles of face sheets and/or the core's thickness, loss factors are increased and natural frequencies are decreased. Lee et al., (2009) investigated the dynamic characteristics of the shape memory alloy (SMA) helical spring due to the martensite - austenite transformation. They showed the laterally loaded helical spring can be regarded as a uniform beam with the equivalent flexural stiffness for intermediate and long springs.

Finding the modal characteristics of free and forced beam vibrations by considering complicating the parameters is an interesting area in engineering vibration. Linear and nonlinear partial differential equations in space and time are presented in order to display the governing equation of the beam vibrations. Another aspect in nonlinear science is nonlinear analysis; it is quite difficult to prepare an exact solution for nonlinear equations to see the effects of other parameters analytically in the analysis; therefore, many researchers have worked on the analytical approximate methods for nonlinear equations.

Recently, some approximate methods have been proposed to solve nonlinear equations such as homotopy perturbation method (He, 1999, Bayat et al., 2013), energy balance method (He, 2002), the max-min approach (He, 2008a), amplitude-frequency formulation (He, 2008b, Pakar and Bayat, 2013), Parameter expanding method (He, 2006), variational approach (He, 2007), Hamiltonian approach (He, 2010a, Ahmadi et al., 2014, Bayat and Pakar, 2012), and variational iteration method (He et al., 2010b).

In this paper the free vibration of laminated composite beams is studied. The paper has the following sections: After the Introduction, the mathematical formulation of the problem of the vibration of laminated composite beams is given. Then, the basic concept of the energy balance method (EBM) and He's amplitude frequency formulation (HAFF) is described. Subsequently, EBM and HAFF are studied to demonstrate the applicability and preciseness of these methods. This is followed by a presentation of some comparisons between analytical and numerical solutions. Finally, it is showed that EBM and HAFF can converge to a precise cyclic solution for laminated composite beams. 


\section{MATHEMATICAL FORMULATION}

Consider a composite laminated beam of length $\mathrm{l}$, height $\mathrm{h}$, width $\mathrm{b}$, and mass density $\rho$ that is subjected to a compressive axial load $\widehat{\mathrm{P}}$. The nondimensional equation governing free, undamped, large-amplitude lateral vibrations measured from the undeformed equilibrium position is given by Emam and Nayfeh (2009).

$$
\ddot{w}+w^{i v}+\left(P-\frac{1}{2} \alpha \int_{0}^{1} w^{\prime 2} d x\right) w^{\prime \prime}+\Lambda\left[w^{\prime}(1, t)-w^{\prime}(0, t)\right] w^{\prime \prime}=0
$$

Where:

(2)

$$
\begin{aligned}
& x=\frac{\hat{x}}{l}, \quad w=\frac{\hat{w}}{r}, \quad t=\hat{t} \sqrt{\frac{\left(D_{11}-\frac{B_{11}^{2}}{A_{11}}\right)}{\rho h l^{4}}}, \quad P=\frac{\hat{P}^{2}}{b\left(D_{11}-\frac{B_{11}^{2}}{A_{11}}\right)}, \\
& \alpha=\frac{A_{11} r^{2}}{D_{11}-\frac{B_{11}^{2}}{A_{11}}}, \quad \Lambda=\frac{B_{11} r}{D_{11}-\frac{B_{11}^{2}}{\Lambda_{11}}}
\end{aligned}
$$

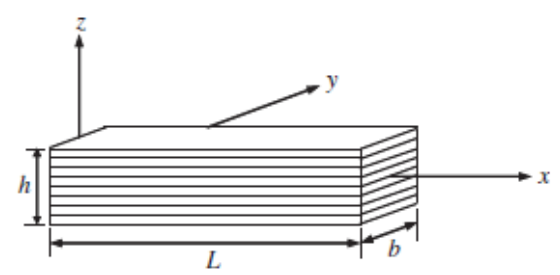

Fig. 1. Geometry of a laminated composite beam

The dot indicates the derivative with respect to time $t$, the prime indicates the derivative with respect to the spatial coordinate $\mathrm{x}$, and the hat identifies the dimensional quantities. $r$ is the radius of gyration of the cross section, $A_{11}, B_{11}, D_{11}$ are the axial, coupling, and bending stiffnesses, respectively and defined as:

$$
A_{11}=\sum_{k=1}^{N}\left(\bar{Q}_{11}\right)_{k}\left(\hat{z}_{k}-\hat{z}_{k-1}\right)
$$


(4)

$$
B_{11}=\frac{1}{2} \sum_{k=1}^{N}\left(\bar{Q}_{11}\right)_{k}\left(\hat{z}_{k}^{2}-\hat{z}_{k-1}^{2}\right)
$$

$$
D_{11}=\frac{1}{3} \sum_{k=1}^{N}\left(\bar{Q}_{11}\right)_{k}\left(\hat{z}_{k}^{3}-\hat{z}_{k-1}^{3}\right)
$$

Where $\bar{Q}_{11_{k}}$ is the reduced-transformed stiffness of the kth lamina, $\hat{z}_{k}$ is its height, and $\mathrm{N}$ is the number of layers. The material properties are assumed not to change within a typical lamina Hyer (1998). The boundary conditions are given by

$$
\begin{aligned}
& w=0 \quad \text { and } \quad w^{\prime \prime}=0 \quad \text { at } \quad x=0,1 \\
& w=0 \quad \text { and } \quad w^{\prime}=0 \quad \text { at } \quad x=0,1
\end{aligned}
$$

For simply supported and clamped-clamped beams, respectively. Emam and Nayfeh (2009) exactly solved the nonlinear static problem of Eq. (1). The static postbuckling response corresponding to the first buckling mode is obtained as follows (Emam, 2013):

$$
w_{s}(x)=b_{s} \sin (\lambda x)
$$

For a simply supported beam and

$$
w_{S}(x)=b_{c}(1-\cos (\lambda x))
$$

For a clamped-clamped beam. Where $b_{s}$ and $b_{c}$ are two constants defined as

$$
\begin{aligned}
& b_{s}=\frac{-4 \Lambda}{\lambda \alpha}+\frac{2}{\sqrt{\alpha}} \sqrt{\frac{P}{\lambda^{2}}-1+\frac{\Lambda^{2}}{\alpha}} \\
& b_{c}=\frac{2}{\sqrt{\alpha}} \sqrt{\frac{P}{\lambda^{2}}-1}
\end{aligned}
$$

And $\lambda^{2}$ is the nondimensional first critical buckling load that is equal to $\pi^{2}$ for simply supported beams and $4 \pi^{2}$ for clamped-clamped beams. It is worth noting that the constant $\Lambda$ vanishes for symmetric laminates, as can be noted in Eq. (2). 
It is important to emphasize that Eq. (1) governs only the nonlinear free vibrations of beams in the prebuckling state. To investigate the nonlinear free vibrations of composite beams in postbuckling, one needs to introduce a dynamic disturbance to the static, buckled, equilibrium position. As such, the total transverse deformation $w(x, t)$ due to a dynamic deformation $v(x, t)$ that takes place around a static equilibrium position $w_{s}$ can be defined as

$$
w(x, t)=w_{s}(x)+v(x, t)
$$

Inserting Eq. (12) into Eq. (1) yields the nondimensional equation governing large-amplitude free vibrations of composite beams in the postbuckling state. The result is (Emam, 2013)

$$
\begin{aligned}
& \ddot{v}+v^{i v}+\lambda^{2} v^{\prime \prime}-\alpha w_{s}^{\prime \prime} \int_{0}^{1} w_{s}^{\prime} v^{\prime} d x-\frac{1}{2} \alpha w_{s}^{\prime \prime} \int_{0}^{1} v^{\prime 2} d x-\alpha v^{\prime \prime} \int_{0}^{1} w_{s}^{\prime} v^{\prime} d x-\frac{1}{2} \alpha v^{\prime \prime} \int_{0}^{1} v^{\prime 2} d x+\Lambda\left[w_{s}^{\prime}(1)-w_{s}^{\prime}(0)\right] v^{\prime \prime} \\
& +\Lambda\left[v^{\prime}(1, t)-v^{\prime}(0, t)\right]\left(w_{s}^{\prime \prime}+v^{\prime \prime}\right)=0
\end{aligned}
$$

In terms of $v$, boundary conditions of simply supported and clamped-clamped boundary conditions are, respectively, given by

$$
\begin{aligned}
& v=0 \quad \text { and } \quad v^{\prime \prime}=0 \quad \text { at } \quad x=0,1 \\
& v=0 \text { and } \quad v^{\prime}=0 \quad \text { at } \quad x=0,1
\end{aligned}
$$

The nonlinear free vibrations of composite beams in prebuckling and postbuckling are governed by Eqs. (1) and (13), respectively. Emam (2013) applied the Galerkin method and derived the governing differential equation of motion as (Ke et al., 2010):

$$
\frac{d^{2} W(t)}{d t^{2}}+\alpha W(t)+\beta W^{2}(t)+\eta W^{3}(t)=0
$$

With initial conditions:

$$
\mathrm{W}(0)=A, \quad \dot{\mathrm{W}}(0)=0
$$

Where coefficients of Eq. (16) are presented in Appendix A (Emam, 2013). 


\section{BASIC IDEA OF HE'S ENERGY BALANCE METHOD (EBM)}

In He's energy balance method (He, 2002), a variational principle for the nonlinear oscillation is established, and then a Hamiltonian is constructed, from which the angular frequency can be readily obtained by collocation method. The results are valid not only for weakly nonlinear systems, but also for strongly nonlinear ones. Some examples reveal that even the lowest order approximations trigger high accuracy (Ganji et al., 2009). In this paper, we consider a general nonlinear oscillator in the form (He, 2002):

$$
u^{\prime \prime}+f(u(t))=0
$$

Since $u$ and $t$ are generalized dimensionless displacement and time variables, respectively, its variational principle can be easily obtained:

$$
\begin{gathered}
J(u)=\int_{0}^{t}\left(-\frac{1}{2} u^{\prime 2}+F(u)\right) d t, \\
F(u)=\int f(u) d u .
\end{gathered}
$$

Therefore, it can be written in the form:

$$
H=\frac{1}{2} u^{\prime 2}+F(u)=F(A)
$$

or

$$
R(t)=\frac{1}{2} u^{\prime 2}+F(u)-F(A)=0
$$

Oscillating systems contain two important physical parameters, i.e. the frequency $\omega$ and the amplitude of oscillation, $A$. So let us consider the initial conditions:

$$
u(0)=A, \quad u^{\prime}(0)=0
$$


And assume that its initial approximate guess can be expressed as:

$$
u(t)=A \cos \omega t
$$

Substituting Eq. (24) into u which term of Eq. (22), yields:

$$
R(t)=\frac{1}{2} \omega^{2} A^{2} \sin ^{2} \omega t+F(A \cos \omega t)-F(A)=0
$$

If, by any chance, the exact solution had been chosen as the trial function, then it would be possible to make $R$ zero for all values of $t$ by appropriate choice of $\omega$. Since (24) is only an approximation to the exact solution, $R$ cannot be made zero everywhere. Collocation at $\omega t=\pi / 4$ gives:

$$
\omega=\sqrt{\frac{2(F(A)-F(A \cos \omega t))}{A^{2} \sin ^{2} \omega \mathrm{t}}}
$$

\subsection{APPLYING EBM}

In order to assess the advantages and the accuracy of the energy balance method; we will apply this method to the discussed system. Its variational formulation can be easily established:

$$
J(v)=\int_{0}^{t}\left\{-\frac{\dot{W}^{2}}{2}+\alpha \frac{W^{2}}{2}+\beta \frac{W^{3}}{3}+\eta \frac{W^{4}}{4}\right\}
$$

It is Hamiltonian, therefore, it can be written in the form:

$$
\left.H=\frac{1}{2} \dot{W}^{2}+\frac{1}{2} \alpha W^{2}+\frac{1}{3} \beta W^{3}+\frac{1}{4} \eta W^{4}\right)
$$

And

$$
R(t)=\frac{1}{2} \dot{W}^{2}+\frac{1}{2} \alpha W^{2}+\frac{1}{3} \beta W^{3}+\frac{1}{4} \eta W^{4}-\frac{1}{2} \alpha \mathrm{A}^{2}-\frac{1}{3} \beta \mathrm{A}^{3}-\frac{1}{4} \eta \mathrm{A}^{4}=0
$$


We will use the trial function to determine the angular frequency $\omega$, i.e.:

$$
W(t)=A \cos (\omega t)
$$

If we substitute (30) into (29), it results the following residual equation:

$$
R(t)=\frac{1}{2} A^{2} \omega^{2} \sin ^{2}(\omega t)+\frac{1}{2} \alpha A^{2} \cos ^{2}(\omega t)+\frac{1}{3} \beta A^{3} \cos ^{3}(\omega t)+\frac{1}{4} \eta A^{4} \cos ^{4}(\omega t)-\frac{1}{2} \alpha A^{2}-\frac{1}{3} \beta A^{3}-\frac{1}{3} \eta A^{4}=0
$$

If we collocate at $\omega t=\frac{\pi}{4}$, we obtain:

$$
\omega_{E B M}=\sqrt{\alpha+\frac{4-\sqrt{2}}{3} \beta A+\frac{3}{4} \eta A^{2}}
$$

According to Eq. (32), we can obtain the following approximate solution:

$$
W(t)=A \cos \left(\sqrt{\alpha+\frac{4-\sqrt{2}}{3} \beta A+\frac{3}{4} \eta A^{2}} \cdot t\right)
$$

\section{BASIC IDEA OF HE'S AMPLITUDE FREQUENCY FORMULATION (HAFF)}

Let us consider the general nonlinear oscillator as follows:

$$
\ddot{u}+N(u, \dot{u}, \ddot{u}, t)=0, \quad \mathrm{u}(0)=A, \quad \dot{\mathrm{u}}(0)=0
$$

where $f(u, \dot{u}, \ddot{u}, t)$ is a function with the nonlinear term.

For a generalized nonlinear oscillator in Eq. (34), we use two trial functions (He, 2008b):

$$
\begin{gathered}
u_{1}=A \cos t \\
u_{2}=A \cos \omega t
\end{gathered}
$$


Substituting $u_{1}$ and $u_{2}$ into Eq. (27):

$$
R_{1}=\ddot{u}_{1}+N\left(u_{1}, \dot{u}_{1}, \ddot{u}_{1}, t\right)
$$

and

$$
R_{2}=\ddot{u}_{2}+N\left(u_{2}, \dot{u}_{2}, \ddot{u}_{2}, t\right)
$$

If, by chance, $u_{1}$ or $u_{2}$, is chosen to be the exact solution, then the residuals, Eq. (37) or Eq. (38), are vanishing completely. In order to use He's amplitude frequency formulation, we set:

$$
R_{11}=\frac{4}{T_{1}} \int_{0}^{T_{\perp}} R_{1} \cos (t) d t, \quad T_{1}=2 \pi
$$

and

$$
R_{22}=\frac{4}{T_{2}} \int_{0}^{\frac{T_{2}}{4}} R_{2} \cos (\omega t) d t, \quad T_{2}=\frac{2 \pi}{\omega}
$$

Applying He's amplitude frequency formulation (He, 2008b), we have:

$$
\omega^{2}=\frac{\omega_{1}^{2} R_{22}-\omega_{2}^{2} R_{11}}{R_{22}-R_{11}}
$$

where:

$$
\omega_{1}=1, \quad \omega_{2}=\omega
$$

Therefore, we can find the approximate frequency from Eq. (41) and Eq. (42). Finally, approximate solution yields:

$$
u(t)=A \cos (\omega t)
$$

\subsection{APPLYING HAFF}

Consider Eq. (16). According to He's amplitude frequency formulation we choose two trial functions $u_{1}=A$ cost and $u_{2}=A \cos \omega t$ where $\omega$ is assumed to be the frequency of the nonlinear oscillator. Substituting $u_{1}$ and $u_{2}$ into Eq. (16), we obtain, respectively, the following residuals. 


$$
R_{1}=-A \cos (t)+\alpha A \cos (t)+\beta A^{2} \cos ^{2}(t)+\eta A^{3} \cos ^{3}(t)
$$

and

$$
R_{2}=-A \omega^{2} \cos (\omega t)+\alpha A \cos (\omega t)+\beta A^{2} \cos ^{2}(\omega t)+\eta A^{3} \cos ^{3}(\omega t)
$$

According to the HAFF, the above residuals can be rewritten in the forms of weighted residuals. A simple calculation yields:

$$
R_{11}=\frac{2}{\pi} \int_{0}^{\frac{\pi}{2}}\left(-A \cos (t)+\alpha A \cos (t)+\beta A^{2} \cos ^{2}(t)+\eta A^{3} \cos ^{3}(t)\right)(\cos (t)) d t
$$

and

$$
R_{22}=\frac{2 \omega}{\pi} \int_{0}^{\frac{\pi}{2 \omega}}\left(-A \omega^{2} \cos (\omega t)+\alpha A \cos (\omega t)+\beta A^{2} \cos ^{2}(\omega t)+\eta A^{3} \cos ^{3}(\omega t)\right)(\cos (\omega t)) d t
$$

Therefore, the approximate frequency reads:

$$
\omega=\sqrt{\alpha+\frac{8 \beta A}{3 \pi}+\frac{3 \eta A^{2}}{4}}
$$

According to Eq. (48), we obtain the following approximate solution:

$$
W(t)=A \cos \left(\sqrt{\alpha+\frac{8 \beta A}{3 \pi}+\frac{3 \eta A^{2}}{4}} \cdot t\right)
$$

\section{DISCUSSION OF THE RESULTS}

In this section, we verify the results of EBM and HAFF with a numerical solution using Runge-Kutta method (RKM). 

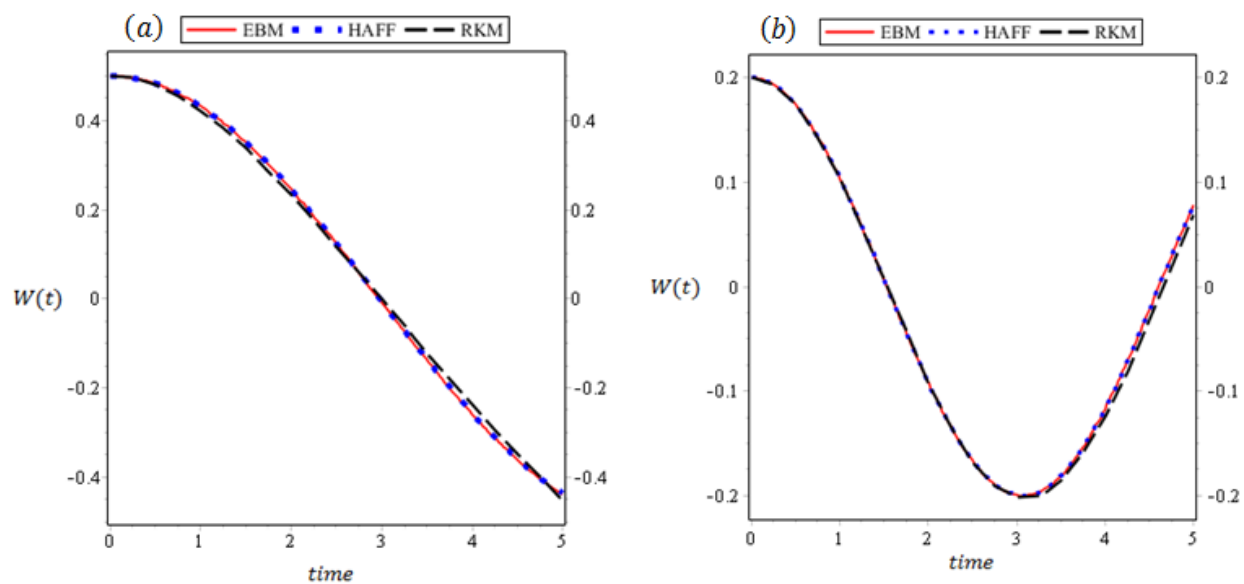

Fig. 2. Comparison of $\mathrm{W}(\mathrm{t})$ versus time diagrams. EBM and HAFF analytical and Runge-Kutta method solution (a): for $A=0.5, \alpha=0.1, \beta=0.2, \eta=0.5$; (b): for $A=0.2, \alpha=1, \beta=0.1, \eta=1$

In Fig. 2, the $\mathrm{W}-\mathrm{t}$ diagrams for two certain groups of parameter values are obtained analytically (EBM and HAFF) and numerically (RKM). The curves are in a good agreement.

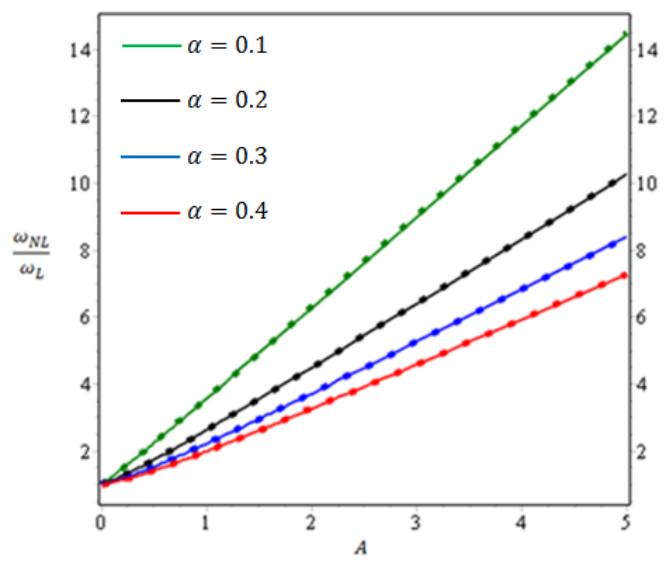

Fig. 3. Comparison of nonlinear to linear frequency ratio corresponding to various parameters of $\alpha$ for $\beta=0.5$ and $\eta=1$ (Solid: EBM, Dot: HAFF) 


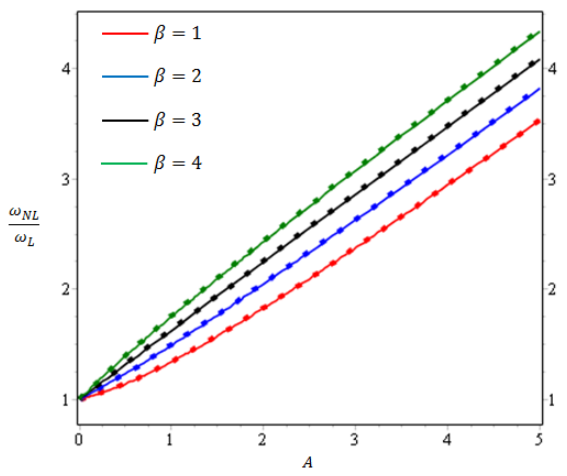

Fig. 4. Comparison of nonlinear to linear frequency ratio corresponding to various parameters of $\beta$ for $\alpha=2$ and $\eta=1$ (Solid: EBM, Dot: HAFF)

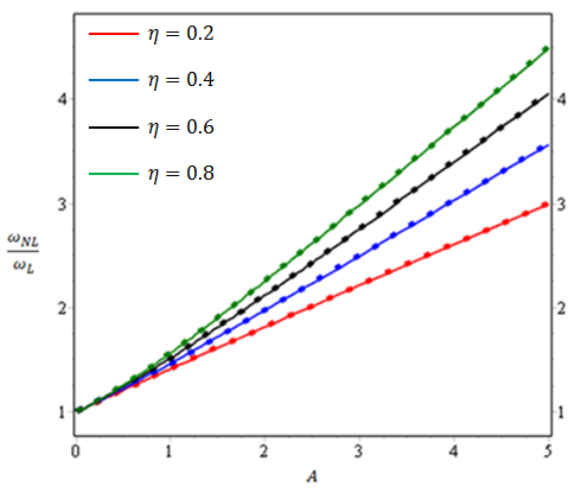

Fig. 5. Comparison of nonlinear to linear frequency ratio corresponding to various parameters of $\eta$ for $\alpha=1$ and $\beta=1$ (Solid: EBM, Dot: HAFF)

Figures 3-5 show the effect of various values of the parameters $\alpha, \beta, \eta$ on the ratio of nonlinear to linear frequency versus non-dimensional amplitude ratio for different cases. In Figure 6-8, a sensitivity analysis of nonlinear to linear frequency ratio for the mentioned parameters is done to complete the results of previous figure. For small amplitudes, the rate of increase in nonlinear fundamental frequency is quite small. The effect of nonlinearity becomes more obvious when the maximum amplitude increases. Results of EBM and HAFF are in good 
numerical agreement byconsidering the effect of different parameters on the response of the problem. The accuracy of the EBM and HAFF results shows that these methods can be easily applied to nonlinear analysis of shell, beam, plate and other nonlinear mechanical systems.
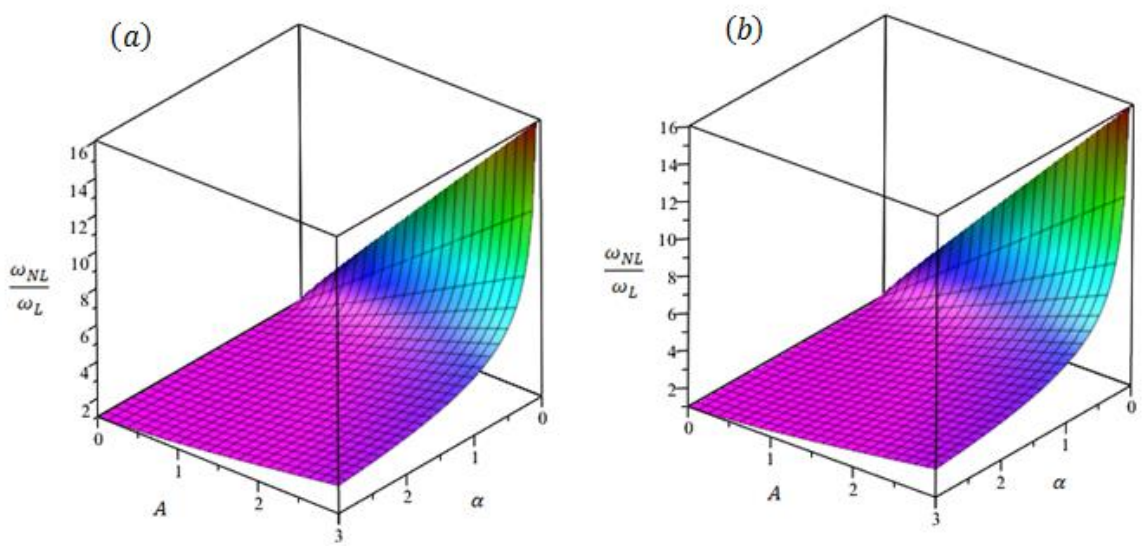

Fig. 6. Sensitivity analysis of nonlinear to linear frequency ratio for $\beta=1$ and $\eta=1$, (a): EBM, (b): HAFF
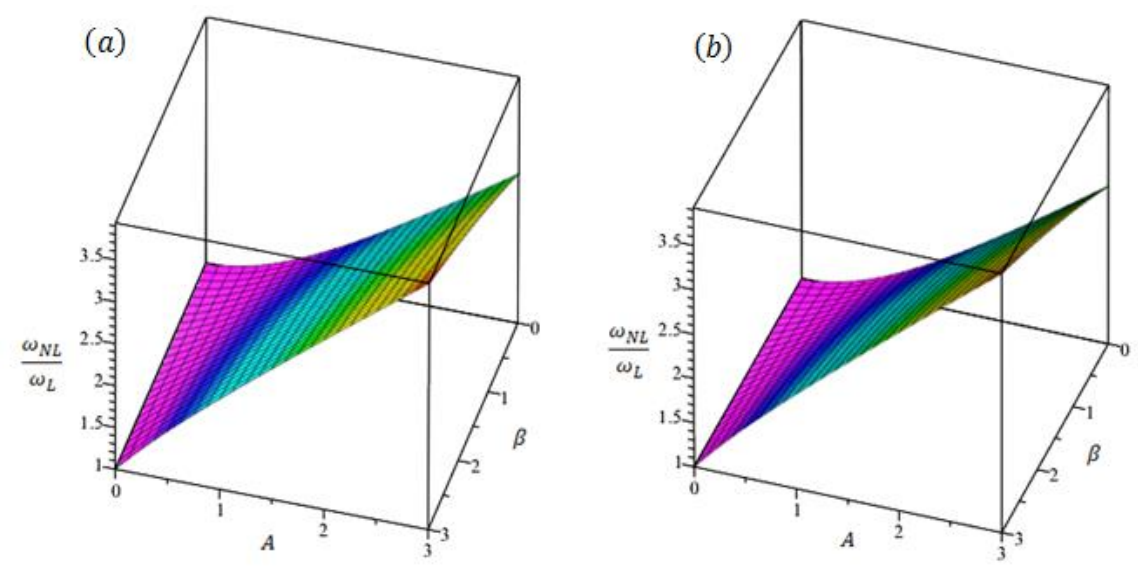

Fig. 7. Sensitivity analysis of nonlinear to linear frequency ratio for $\alpha=1$ and $\eta=1$, (a): EBM, (b): HAFF 

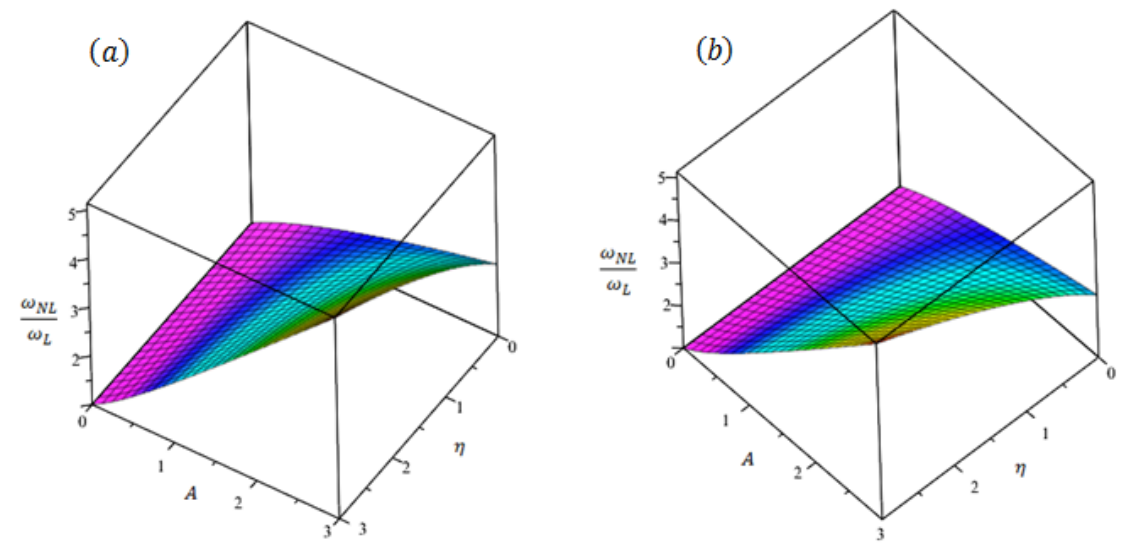

Fig. 8. Sensitivity analysis of nonlinear to linear frequency ratio for $\alpha=1$ and $\beta=2$, (a): EBM, (b): HAFF

\section{Conclusions}

It can be concluded that:

1. The EBM and HAFF methods have been successfully applied to obtain an accurate analytical solution for the nonlinear vibration in the buckling of laminated composite beams.

2. It has been illustrated that the results of EBM and HAFF are in a good agreement with those obtained by the numerical method.

3. The influences of the parameters of laminated composite beams on the vibration are as follows: As it is shown, the amplitude of the oscillation has a great effect on the vibrations of the composite beams in buckling. From the relationships of the parameters in Appendix A, the axial load, stiffness, number of layers, and radius of gyration of the cross section of the laminated composite beams in buckling also have great effects on the response of the vibration. 


\section{APPENDiX A}

The constants and parameters of Eq. (17) for simply supported and clamped-clamped beams in the prebuckling state:

\begin{tabular}{|c|c|c|c|}
\cline { 2 - 4 } \multicolumn{1}{c|}{} & $\alpha$ & $\beta$ & $\eta$ \\
\hline Simply supported beams & $\pi^{2}\left(\pi^{2}-P\right)$ & $2 \pi^{3} \Lambda$ & $\frac{1}{4} \pi^{4} \alpha$ \\
\hline Clamped-clamped beams & $\frac{4}{3} \pi^{2}\left(4 \pi^{2}-P\right)$ & 0 & $\frac{1}{3} \pi^{4} \alpha$ \\
\hline
\end{tabular}

The constants and parameters of Eq. (17) for simply supported and clamped-clamped beams in the postbuckling state:

\begin{tabular}{|c|c|c|c|}
\cline { 2 - 4 } \multicolumn{1}{c|}{} & $\alpha$ & $\beta$ & $\eta$ \\
\hline Simply supported beams & $2 \pi^{2}\left(P-\pi^{2}+\frac{4 \Lambda}{\sqrt{\alpha}} \sqrt{P-\pi^{2}}\right)$ & $\frac{3}{2} \pi^{3} \sqrt{\alpha\left(P-\pi^{2}\right)}$ & $\frac{1}{4} \pi^{4} \alpha$ \\
\hline Clamped-clamped beams & $\frac{8}{3} \pi^{2}\left(P-4 \pi^{2}\right)$ & $2 \pi^{3} \sqrt{\alpha\left(P-4 \pi^{2}\right)}$ & $\frac{1}{3} \pi^{4} \alpha$ \\
\hline
\end{tabular}

\section{REFERENCES}

1. M. I. Qaisi, Application of the harmonic balance principle to the nonlinear free vibration of beams, Appl. Acoust. 40 (1993) 141-51.

2. Q. Guo, H. Zhong, Nonlinear vibration analysis of beams by a spline-based differential quadrature method. J. Sound. Vib. 269 (2004) 413-20.

3. W. C. Xie, H. P. Lee, S. P. Lin, Normal modes of a nonlinear clamped-clamped beam. J. Sound. Vib. 250(2) (2002) 339-49.

4. A. H. Nayfeh, S. A. Nayfeh, Nonlinear normal modes of a continuous system with quadratic nonlinearities. J. Vib. Acoust. Trans. ASME. 117(2) (1995) 199-205.

5. G. R. Bhashyam, G. Prathap, Galerkin finite element method for nonlinear beam vibrations. J. Sound. Vib. 72 (1980) 91-203.

6. E. N. M. Carlos, E. S. S. Ma'rio, G. P. B. Odulpho, Nonlinear normal modes of a simply supported beam: continuous system and finite element models. Comput. Struct. 82 (2004) 2683-91.

7. L. Azrar, R. Benamar, R. G. White, A semi-analytical approach to the nonlinear dynamic response problem of $\mathrm{S}-\mathrm{S}$ and $\mathrm{C}-\mathrm{C}$ beams at large vibration amplitudes Part I: general theory and application to the single mode approach to free and forced vibration analysis. J. Sound. Vib. 224 (1999) 183-207.

8. R. K. Gupta, B. G. Jagadish, G. R. Janardhan, G. Rao, Relatively simple finite element formulation for the large amplitude free vibrations of uniform beams. Finite. Elem. Anal. Des. 2009;45:624-31.

9. R. K. Kapania, S. Raciti, Nonlinear vibrations of unsymmetrically laminated beams. AIAA. J. 27 (1989) 201-10. 
10. G. Singh, G. Rao, N. G. R. Iyengar, Analysis of the nonlinear vibrations of unsymmetrically laminated composite beams. AIAA. J. 29(10) (1991) 1727-35.

11. M. Ganapathi, B. P. Patel, J. Saravanan, M. Touratier, Application of spline element for large-amplitude free vibrations. Composites. Part. B. 29 (1998) 1-8.

12. P. Malekzadeh, A. R. Vosoughi, DQM Large amplitude vibration of composite beams on nonlinear elastic foundations with restrained edges. Commun. Nonlinear. Sci. Numer. Simulat. 14 (2009) 906-15.

13. M. Kisa, Free vibration analysis of a cantilever composite beam with multiple cracks. Compos. Sci. Technol. 64(9) (2004) 1391-1402

14. M. Arvin, M. Sadighi, A. R. Ohadi, A numerical study of free and forced vibration of composite sandwich beam with viscoelastic core. Compos. Struct. 92(4) (2010) 996-1008.

15. C. Lee, H. Zhuo, C. Hsu, Lateral vibration of a composite stepped beam consisted of SMA helical spring based on equivalent Euler-Bernoulli beam theory, J. Sound. Vib. 324 (2009) 179-193.

16. H. J. He, Homotopy Perturbation technique. Comput. Method. Appl. M. 178 (1999) 257-262.

17. M. Bayat, I. Pakar, A. Emadi, Vibration of electrostatically actuated microbeam by means of homotopy perturbation method. Struct. Eng. mech. 48(6) (2013) 823-831.

18. J. H. He, Preliminary report on the energy balance for nonlinear oscillations. Mech. Res. Commun. 29 (2002) $107-111$.

19. J. H. He, Max-min approach to nonlinear oscillators. Int. J. Non. Sci. Num. 9(2) (2008a) 207-210.

20. J. H. He, An improved amplitude-frequency formulation for nonlinear oscillators. Int. J. Non. Sci. Num. 9(2) (2008b) 211-212.

21. Pakar, M. Bayat, Vibration analysis of high nonlinear oscillators using accurate approximate methods. Struct. Eng. Mech. 46(1) (2013) 137-151.

22. H. He, Some asymptotic methods for strongly nonlinear equations. Int. J. Mod. Phys. B. 20(10) (2006) 1141-1199.

23. H. He, Variational Approach for nonlinear oscillators. Chaos. Soliton. Fract. 34 (2007) 1430-1439.

24. J. H. He, Hamiltonian Approach to nonlinear oscillators. Phys. Lett. A. 374 (2010a) 2312-2314.

25. Ahmadi, G. Hashemi, A. Asghari, Application of iteration perturbation method and Hamiltonian approach for nonlinear vibration of Euler-Bernoulli beams, Lat. Am. J. Solids. Struct, 11(6) (2014) 1049-1062.

26. Bayat, I. Pakar, Accurate analytical solution for nonlinear free vibration of beams. Struct. Eng. Mech. 43(3), 2012, 337-347.

27. J. H. He, G. C. Wu, F. Austin, The variational iteration method which should be followed. Nonlinear. Sci. Lett. A. 1(1) (2010b), 1-30.

28. S. A. Emam, A. H. Nayfeh, Postbuckling and free vibration of composite beams. Compos. Struct. (2009) 88:636-42.

29. W. Hyer, Stress Analysis of Fiber-Reinforced Composite Materials. (McGraw- Hill; 1998).

30. S. A. Emam, Approximate analytical solutions for the nonlinear free vibrations of composite beams in buckling. Compos. Struct. 100 (2013) 186-194.

31. L. Ke, J. Yang, S. Kitipornchai, An analytical study on the nonlinear vibration of functionally graded beams. Meccanica. 45(6) (2010) 743-752.

32. S. S. Ganji, S. Karimpour, D. D. Ganji, Z. Z. Ganji, Periodic solution for strongly nonlinear vibration systems by energy balance method, Acta Appl. Math. 106(1) (2009) 79-92. 


\section{LIST OF FIGURES AND TABLES:}

Fig. 1. Geometry of a laminated composite beam

Rys. 1. Geometria laminowanej belki kompozytowej

Fig. 2. Comparison of $W(t)$ versus time diagrams. EBM and HAFF analytical and Runge - Kutta method solution (a): for $A=0.5, \alpha=0.1, \beta=0.2, \eta=0.5$; (b): for $A=0.2, \alpha=1, \beta=0.1, \eta=1$

Rys. 2. Porównanie schematów W(t) względem czasu. Rozwiązanie metodami analitycznymi EBM i HAFF oraz metodą Rungego - Kutty (a): dla $A=0.5, \alpha=0.1, \beta=0.2, \eta=0.5$; (b): dla $A=0.2, \alpha=1, \beta=0.1, \eta=1$

Fig. 3. Comparison of nonlinear to linear frequency ratio corresponding to various parameters of $\alpha$ for $\beta=0.5$ and $\eta=1$, Solid: EBM, Dot: HAFF

Rys. 3. Porównanie stosunku częstotliwości drgań nieliniowych do liniowych, odpowiadającego różnym parametrom $\alpha$ dla $\beta=0.5$ i $\eta=1$, linia ciągła: EBM, linia przerywana: HAFF

Fig. 4. Comparison of nonlinear to linear frequency ratio corresponding to various parameters of $\beta$ for $\alpha=2$ and $\eta=1$, Solid: EBM, Dot: HAFF

Rys. 4. Porównanie stosunku częstotliwości drgań nieliniowych do liniowych, odpowiadającego różnym parametrom $\beta$ dla $\alpha=2$ and $\eta=1$, linia ciągła: EBM, linia przerywana: HAFF

Fig. 5. Comparison of nonlinear to linear frequency ratio corresponding to various parameters of $\eta$ for $\alpha=1$ and $\beta=1$, Solid: EBM, Dot: HAFF

Rys. 5. Porównanie stosunku częstotliwości drgań nieliniowych do liniowych, odpowiadającego różnym parametrom $\eta$ dla $\alpha=1$ and $\beta=1$, linia ciągła: EBM, linia przerywana: HAFF

Fig. 6. Sensitivity analysis of nonlinear to linear frequency ratio for $\beta=1$ and $\eta=1$, (a): EBM, (b): HAFF

Rys. 6. Analiza wrażliwości stosunku częstotliwości drgań nieliniowych do liniowych dla $\beta=1$ and $\eta=1$,

(a): EBM, (b): HAFF

Fig. 7. Sensitivity analysis of nonlinear to linear frequency ratio for $\alpha=1$ and $\eta=1$, (a): EBM, (b): HAFF

Rys. 7. Analiza wrażliwości stosunku częstotliwości drgań nieliniowych do liniowych dla $\alpha=1$ and $\eta=1$,

(a): EBM, (b): HAFF

Fig. 8. Sensitivity analysis of nonlinear to linear frequency ratio for $\alpha=1$ and $\beta=2$, (a): EBM, (b): HAFF

Rys. 8. Analiza wrażliwości stosunku częstotliwości drgań nieliniowych do liniowych dla $\alpha=1$ and $\beta=2$,

(a): EBM, (b): HAFF 


\title{
ANALIZA DRGAŃ NIELINIOWYCH PRZED I PO WYBOCZENIU
}

\section{LAMINOWANYCH BELEK KOMPOZYTOWYCH}

\author{
Stowa kluczowe: drgania nieliniowe, belki kompozytowe, metody analityczne
}

\section{STRESZCZENIE:}

Niniejsze opracowanie podejmuje temat analizy swobodnych drgań nieliniowych wyboczenia laminowanych belek kompozytowych. Zastosowano dwie nowe metody w celu uzyskania rozwiązania w postaci kluczowego równania nieliniowego, opisującego ten problem.

Przestudiowano wpływ różnych parametrów na stosunek częstotliwości drgań nieliniowych do drgań liniowych w odniesieniu do badanych belek. Metody te umożliwiły nam weryfikację otrzymanych wyników dla całego zakresu amplitudy oscylacji.

Wnioski z przeprowadzonych badań i analiz są następujące:

1. Metody EBM i HAFF zostały $\mathrm{z}$ sukcesem zastosowane w celu otrzymania precyzyjnego rozwiązania analitycznego problemu drgań nieliniowych w wyboczeniu laminowanych belek kompozytowych.

2. Wykazano, że wyniki EBM i HAFF zgadzają się z wynikami otrzymanymi za pomocą metody liczbowej.

3. Wpływ parametrów laminowanych belek kompozytowych na drgania jest następujący: Jak wykazano, amplituda oscylacji ma ogromny wpływ na drgania belek kompozytowych w trakcie wyboczenia. Zależności pomiędzy parametrami określonymi w Załączniku A, takimi, jak obciążenie osiowe, sztywność, liczba warstw oraz promień bezwładności przekroju laminowanych belek kompozytowych ulegających wyboczeniem mają również ogromny wpływ na drgania. 